\title{
Tef (Eragrostis tef Trotter) Responses to Nitrogen Fertigation under Semi-Arid Mediterranean Climate
}

\author{
Kelem Gashu ${ }^{1,2}$, Moshe Halpern ${ }^{1}$, Isaac Zipori ${ }^{1}$, Amnon Bustan ${ }^{3}$, Yehoshua Saranga ${ }^{2}$ \\ and Uri Yermiyahu $1, *$ (D) \\ 1 Gilat Research Center, Agricultural Research Organization, Gilat 85280, Israel; \\ kelem-ga.alamrie@mail.huji.ac.il (K.G.); moshehalpern416@hotmail.com (M.H.); \\ matabsor@volcani.agri.gov.il (I.Z.) \\ 2 The Robert H. Smith Faculty of Agriculture, Food and Environment, The Hebrew University of Jerusalem, \\ Rehovot 76100, Israel; shuki.saranga@mail.huji.ac.il \\ 3 Desert Agro-Research Center (DARC), Ramat Negev R\&D, Ramat Negev Works Ltd., Halutza 8551500, Israel; \\ amnonbustan@gmail.com \\ * Correspondence: uri4@volcani.agri.gov.il
}

Received: 14 October 2020; Accepted: 24 November 2020; Published: 27 November 2020

\begin{abstract}
Eragrostis tef (Zucc.) Trotter (tef) is a small annual grain, panicle-bearing, $\mathrm{C}_{4}$ cereal crop native to Ethiopia, where it is a major staple food. The objectives of the present study were to characterize the responses of two tef genotypes to escalating nitrogen $(\mathrm{N})$ levels in terms of shoot, root, and grain biomass production, $\mathrm{N}$ concentration and uptake, and to determine an optimum $\mathrm{N}$ range at which tef performance is maximized. The $\mathrm{N}$ was applied in the irrigation water (Fertigation) in order to provide a consistent concentration of $\mathrm{N}$ in the root zone. A second goal was to test the feasibility of growing tef in the hot, arid conditions of the Northern Negev Desert. Two experiments were carried out in the Gilat Research Station (Negev region, Israel), each testing two different genotypes of tef (405B and 406W), and each including five replicates for each treatment. In the winter of 2015-2016, tef plants were grown in perlite filled pots in a walk-in plastic-covered tunnel. Five different $\mathrm{N}$ treatments were applied through fertigation, meaning the fertilizer was applied with the irrigation water $\left(10,20,40,80,120 \mathrm{mg} \mathrm{L}^{-1}\right)$. All other nutrients were applied at the same sufficient rate. In the summer of 2016, tef plots were sown in open-field and applied with four different rates of $\mathrm{N}$ fertilization $\left(0,30,60,120 \mathrm{mg} \mathrm{L}^{-1}\right)$. Biomass of the different plant parts, SPAD values, $\mathrm{N}, \mathrm{P}$ and $\mathrm{K}$ concentration, and the lodging index were recorded in each experiment. The harvest index was also calculated. Optimum $\mathrm{N}$ fertigation concentration in both experiments was between 40 and $80 \mathrm{mg} \mathrm{L}^{-1}$, under which the time to flowering was decreased, and yield and grain protein concentration were optimized. Underfertilization caused a decrease in overall plant growth, whereas overfertilization caused an increase in vegetative growth at the expense of grain yield. Potassium uptake increased along with increased $\mathrm{N}$ availability, whereas $\mathrm{P}$ uptake did not. The fertilization rate will always need to take into account local soil and climate conditions. The field experiment also pointed to low harvest index as a major limitation on tef cultivation in the Northern Negev.
\end{abstract}

Keywords: tef; fertigation; nitrogen; growth parameters; yield; harvest index

\section{Introduction}

Tef [Eragrostis tef (Zucc.) Trotter] is a small annual grain, panicle-bearing, $\mathrm{C}_{4}$ cereal crop native to Ethiopia, where it is a major staple food [1]. It has been grown for thousands of years in Ethiopia [2] and is used to make fermented dough, of which the local traditional bread, injera, is prepared [3]. The tef grains is considered the smallest of all cereals, with thousand-grain weight ranging between 
200 and $400 \mathrm{mg}$ [4]. The color of the grain ranges from dark brown to yellowish-white, depending on the genotype. Tef grains are gluten-free [5] and rich in vitamins, minerals, and essential amino acids compared to other grains [2,6-8]. Due to these characteristics, tef is considered a "superfood" and is a desired ingredient in health products, particularly for celiac and diabetes patients [7]. Tef is also known as a high-quality animal feed [6,9].

The vast majority of tef cultivation is limited to Ethiopia and Eritrea, which are the only countries that currently utilize this plant for cereal [10]. However, tef shows promise as an emerging crop for dry and marginal lands [10]. Tef is adapted to a large variety of environmental conditions and widely grown from sea level up to $2800 \mathrm{~m}$ above sea level, under various rainfall, temperature, and soil conditions [9]. Tef is known to tolerate water-logging [11] and tolerates salinity and drought stress better than many other crops [10]. There are reports of specific cultivars of tef, which are more drought-resistant than others [12]. Currently, tef productivity is low compared to other cereals, with an average grain yield of $1664 \mathrm{~kg} \mathrm{ha}^{-1}$ in 2017 in Ethiopia compared to $3675 \mathrm{~kg} \mathrm{ha}^{-1}$ for maize and $2525 \mathrm{~kg} \mathrm{ha}^{-1}$ for sorghum that same year [13]. However, using new genotypes and optimum management practices, yield potential in an experimental setting can reach as high as $4599 \mathrm{~kg} \mathrm{ha}^{-1}$ [14].

Nitrogen is required by plants in relatively large amounts [15]. $\mathrm{N}$ fertilization is widely applied in tef cultivation [16]. Studies in diverse districts of Ethiopia have shown that increasing levels of $\mathrm{N}$ fertilization can have positive effects on yield and other growth parameters of tef [17-19]. A study of tef growing in a Mediterranean climate showed the same trends [1]. However, excessive application of $\mathrm{N}$ fertilizer can lead to lodging and grain loss in tef $[19,20]$, an effect that has been observed in many grain crops [21-23]. Furthermore, the excess $\mathrm{N}$ released into the environment degrades air and water quality and contributes to anthropogenic climate change [24].

Though there are many studies that examined the effect of $N$ fertilization levels on tef growth [20,25-27], to the best of our knowledge, $\mathrm{N}$ requirements of tef have never been determined under controlled, favorable conditions that eliminate local restrictions such as soil properties, weather conditions, and water availability. The use of perlite as an artificial growth medium provides excellent conditions to evaluate plant nutritional requirements. Perlite has negligible nutrient content and ion exchange [28], meaning that the roots of the plant are exposed to the nutrient concentrations supplied in the irrigation water. Nitrogen fertigation in natural soils has been studied on other staple crops such as wheat (Triticum aestivum L.) [29], potatoes (Solanum tuberosum L.) [30], rice (Oryza sativa L.) [31], and corn (Zea mays L.) [32]. Fertigation combined with a perlite growth medium has been used as an experimental system in other crops such as tomatoes (Solanum lycopersicum L.) [33], pepper (Capsicum annuum L.) [34,35], and cassava (Manihut esculenta Crantz) [36]. However, to the best of our knowledge, tef has not been studied using fertigation in natural soils or in a fertigation-perlite system. Combining perlite and a precisely managed fertigation technology is expected to eliminate confounding factors such as soil properties and water availability, thus elucidating the net response of the crop to various $\mathrm{N}$ levels.

One objective of the present study was to characterize the responses of tef to escalating $\mathrm{N}$ levels and to determine an $\mathrm{N}$ range at which tef performance is at an optimum, carried out in a controlled environment without the variability of soil, nutrients, water, and pests that are usually present in field trials. To this end, a pot experiment was conducted in a protective plastic tunnel in perlite filled pots with controlled nutrient and water inputs in the winter of 2015-2016. A second experiment that evaluated the response of tef to $\mathrm{N}$ fertigation was conducted in the field in the summer of 2016. The purpose of this experiment was two-fold. First, we wanted to determine whether the response of tef to escalating $\mathrm{N}$ in the field was similar to the response in the protected environment, despite the large disparity in the conditions. An additional goal of the field experiment was to test the feasibility of growing tef in the hot, arid conditions of the Northern Negev Desert (Israel). Together, these two experiments were designed to improve our understanding of tef response to $\mathrm{N}$ fertilizer and to open new horizons for tef production outside its traditional range. 


\section{Materials and Methods}

\subsection{Plant Materials and Experimental Design}

Two tef genotypes from the Israel Gene Bank (Agricultural Research Organization, Volcani Center, Rishon Lezion, Israel) were used in the current study, RTC-405 and RTC 406 (denoted hereafter as 405B and 406W, with the last letter indicating brown ot white seed color). The entire collection was propagated and initially phenotyped in a common garden experiment during spring 2015 [37]. The two genotypes selected for the current study exhibited diverse phenotypes, with 405B characterized by early phenology, thin columns, high tillering capacity and brown seeds, whereas 406W characterized by medium phenology, thick columns, medium tillering capacity and white seeds.

A pot experiment was conducted in a walk-in plastic-covered tunnel $(6 \mathrm{~m}$-wide, $2.4 \mathrm{~m}$ tall and $30 \mathrm{~m}$-long) at the Gilat Research Center, Israel, Negev, Israel during winter 2015-2016. The experiment comprised of five treatments of $N$ concentrations in the irrigation solution: $(10,20,40,80$ and $120 \mathrm{mg} \mathrm{L}^{-1}$ ) and two tef genotypes (405B and 406W). No $0 \mathrm{mg} \mathrm{L}^{-1}$ treatment was included since perlite is functionally devoid of nutrients, and without any $\mathrm{N}$ input, the plants simply would not grow. A factorial ( $\mathrm{N}$ treatments $\times$ genotypes) randomized block design was employed with five replicates. In all treatments, $\mathrm{N}$ was applied as $90 \% \mathrm{NO}_{3}{ }^{-}$and $10 \% \mathrm{NH}_{4}{ }^{+}$. Tef plants were grown in $3 \mathrm{~L}$ plastic pots containing perlite (medium size $1.2 \mathrm{~mm}$, Agrifusia, Fertilizer \& Chemicals Ltd. Haifa, Israel) as a growth medium. Seeds of two tef genotypes were sown on 15 December 2015. Initially, all pots were drip-irrigated with a solution containing $40 \mathrm{mg} \mathrm{L}^{-1} \mathrm{~N}, 6 \mathrm{mg} \mathrm{L}^{-1} \mathrm{P}, 40 \mathrm{mg} \mathrm{L}^{-1} \mathrm{~K}, 20 \mathrm{mg} \mathrm{L}^{-1} \mathrm{Ca}$, $20 \mathrm{mg} \mathrm{L}^{-1} \mathrm{Mg}, 28 \mathrm{mg} \mathrm{L}^{-1} \mathrm{~S}, 0.3 \mathrm{mg} \mathrm{L}^{-1} \mathrm{~B}, 0.6 \mathrm{mg} \mathrm{L}^{-1} \mathrm{Fe}, 0.3 \mathrm{mg} \mathrm{L}^{-1} \mathrm{Mn}, 0.15 \mathrm{mg} \mathrm{L}^{-1} \mathrm{Zn}, 0.02 \mathrm{mg} \mathrm{L}^{-1}$ $\mathrm{Cu}$, and $0.02 \mathrm{mg} \mathrm{L}^{-1}$ Mo. Thinning was carried out three weeks after emergence, and 15 plants per pot remained for the entire experiment. Twenty-five days after sowing, differential $\mathrm{N}$ treatments were initiated, with all other nutrients kept constant throughout the entire experiment at their initial concentrations, determined based on a preliminary experiment (data not shown). Pots were irrigated with final solutions, according to treatments via a drip system, until leaching began, which indicated the perlite had reached water holding capacity.

A field experiment was also conducted at the Gilat Research Center during the summer of 2016. The soil was sandy loam loess soils, calcaric fluvisols (WRB) or typic torrifluvents (USDA taxonomy), containing $55 \%$ sand, $30 \%$ silt and $15 \%$ clay. The experiment included four $\mathrm{N}$ levels: $(0,30,60$ and $120 \mathrm{mg} \mathrm{L}^{-1}$ in the irrigation water) and two tef genotypes (405B and 406W). Since the soil has a buffering capacity to adjust $\mathrm{pH}, \mathrm{N}$ was applied as $70 \% \mathrm{NO}_{3}{ }^{-}$and $30 \% \mathrm{NH}_{4}$ in all treatments. Concentrations of all other minerals were identical to those used in the pot experiment.

A factorial ( $\mathrm{N}$ treatments $\times$ genotypes) split-plot block design with 5 replications was used, with fertigation treatment in the main plots and genotypes in subplots. Each main plot (5 $\mathrm{m}$ long $\times$ $4.2 \mathrm{~m}$ wide) consisted of 28 rows (14 rows per genotype) with $15 \mathrm{~cm}$ space between rows. Each main plot was irrigated by 14 drip lines between each pair of rows. Seeds were directly sown on 13 July 2016 into well-prepared dry soil at a depth of $\sim 1 \mathrm{~cm}$, and seeding rate of $800 \mathrm{mg} / \mathrm{m}^{2}$, using a hand-driven precision garden seeder (1001B, Earthway, Bristol, IN, USA). During the first two weeks, plots were irrigated to drainage in order to avoid salt accumulation. Two weeks after sowing, fertigation treatments were started by injecting $1 \mathrm{~L}$ of custom-made fertilizer solutions into $100 \mathrm{~L}$ of water. Fertigation was applied daily via a drip system with water amounts determined according to penman Monteith potential evapotranspiration [37] multiplied by the following crop coefficients: 1.0 for the first 26 days after sowing, 1.2 for 26-30 days, 1.0 for 30-40 days, 1.2 for 40-60 days, 1.0 for $60-70$ days and 0.8 from 70 days after sowing to the final harvest as described by Yihun, et al. [38].

Meteorological data for the duration of the experimental period was measured onsite outdoors (Figure 1). The plants grown in the plastic-covered tunnel in the winter pot experiment were exposed to approximately $50 \%$ of the natural solar radiation presented in Figure 1. 


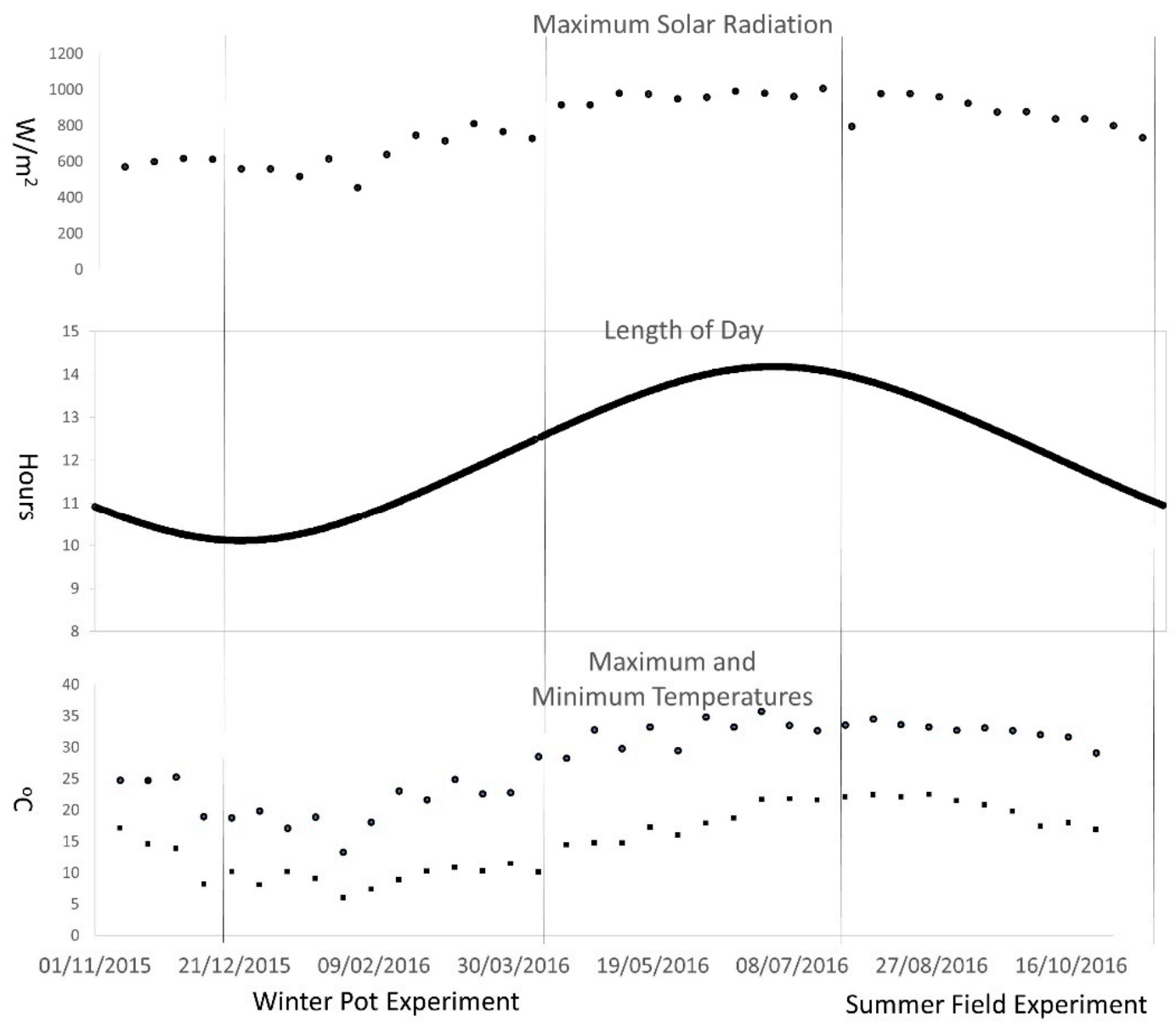

Figure 1. Solar radiation (top), hours of daylight (middle), and maximum and minimum temperatures (bottom) measured at the Gilat Research station during the year when the two experiments took place. The time frame of each experiment is blocked off at the bottom of the figure.

\subsection{Data Collection}

In both experiments, days to $50 \%$ panicle emergence was recorded for each pot and plot by visual observation. The youngest fully expanded leaves from representative plants were selected and used for indirect chlorophyll measurement using SPAD 502 (Minolta Corporation, Ramsey, NJ, USA) chlorophyll meter ( 85 and 50 days after emergence for pot and field experiment, respectively). In both experiments, plants were sampled twice: at flowering stage (50 and 40 days after sowing for pot and field experiment, respectively) and at maturity stage (final harvest), at 105 (405B) and 114 (406W) days after sowing in the pot experiment, and at 84 and 99 days after sowing (405B and 406W genotypes, respectively) in the field experiment. In the pot experiment, two repetitions, which included 50 pots ( 25 pots for each sampling time), were sampled by destructive harvest, whereas in the field experiment, tef plants were sampled from $1 \times 1 \mathrm{~m}$ measured area in each sub-plot. Sampling was done for both genotypes at the same time.

The number of tillers per plant was recorded at harvest time. The height and panicle length of the plant was measured at the end of the growing season. In the pot experiment, the roots were separated from shoots and washed off any loose perlite with tap water and placed into a paper bag. The shoots were then rinsed several times in distilled water to avoid any contaminants and placed in a different paper bag. Both plant parts were oven-dried for $72 \mathrm{~h}$ at $70^{\circ} \mathrm{C}$, weighed to determine the dry matter. Shoots were subsequently used for nutrient analysis.

Lodging was evaluated visually at the end of the winter pot experiment using the following scale: $<20 \%$ lodged $=1,20-40 \%$ lodged $=2,40-60 \%$ lodged $=3,60-80 \%$ lodged $=4,80-100 \%$ lodged $=5$. 
In the summer field experiment, all the plots were fully lodged by the end of the experiment and, therefore, were not evaluated.

Once harvested, the grains were separated from the straw by hand (pot experiment) or threshing machine (field experiment). The dried tef shoots were then ground in a grinding machine. Approximately $0.1 \mathrm{~g}$ of the ground samples and grain was digested by $2 \mathrm{~mL}$ sulfuric acid under $180^{\circ} \mathrm{C}$ and supplemented with hydrogen peroxide. The concentration of $\mathrm{N}$ was determined by an autoanalyzer (Lachat Instruments, Milwaukee, WI, USA). Mineral uptake of shoot and grain was calculated by multiplying each mineral concentration with respective vegetative DM and grain yield.

Before treatments were applied in the field trial, soil samples from three layers $(0-30 \mathrm{~cm}, 30-60 \mathrm{~cm}$, and 60-90 cm-depth) were collected at five locations within the experimental plot. Soil samples were then oven-dried for $96 \mathrm{~h}$ at $70{ }^{\circ} \mathrm{C}$ and grounded to pass through $2 \mathrm{~mm}$ sieve. Soil analysis included: $\mathrm{pH}$, electrical conductivity (EC), moisture content, $\mathrm{K}, \mathrm{P}, \mathrm{NO}_{3}, \mathrm{Mg}, \mathrm{Na}$ and $\mathrm{Cl}$ in a saturated paste. Ammonium was extracted by potassium chloride $(\mathrm{KCl} 1 \mathrm{M})$ and determined by an autoanalyzer (Lachat Instruments, Milwaukee, WI, USA). Average values of these soil properties at each depth are presented in Table 1.

Table 1. Soil chemical properties (mean and standard errors) before treatment application.

\begin{tabular}{ccccccccc}
\hline \multicolumn{10}{c}{ Soil Chemical Properties } \\
\hline $\begin{array}{c}\text { Depth } \\
(\mathbf{c m})\end{array}$ & $\begin{array}{c}\text { EC } \\
(\mathbf{d S} / \mathbf{m})\end{array}$ & $\mathbf{p H}$ & $\begin{array}{c}\text { Water } \\
\text { Content }\end{array}$ & $\begin{array}{c}\mathbf{K} \\
\mathbf{( m g} / \mathbf{L})\end{array}$ & $\begin{array}{c}\mathbf{C l} \\
(\mathbf{m g} / \mathbf{L})\end{array}$ & $\begin{array}{c}\mathbf{P} \\
(\mathbf{m g} / \mathbf{L})\end{array}$ & $\begin{array}{c}\mathbf{N O}_{3} \\
(\mathbf{m g} / \mathbf{L})\end{array}$ & $\begin{array}{c}\mathbf{N H}_{\mathbf{4}} \\
(\mathbf{m g} / \mathbf{k g} \text { soil) }\end{array}$ \\
\hline $0-30$ & $1.16 \pm 0.09$ & $7.9 \pm 0.06$ & $56 \pm 1.8$ & $38.8 \pm 7.1$ & $90.2 \pm 20.8$ & $1.1 \pm 0.21$ & $0.2 \pm 0.04$ & $3.0 \pm 0.39$ \\
$30-60$ & $0.75 \pm 0.07$ & $8.2 \pm 0.05$ & $55 \pm 1.0$ & $8.7 \pm 2.2$ & $74.2 \pm 11.6$ & $0.7 \pm 0.09$ & $0.3 \pm 0.18$ & $0.9 \pm 0.11$ \\
$60-90$ & $0.91 \pm 0.22$ & $8.2 \pm 0.09$ & $53 \pm 1.8$ & $3.7 \pm 0.7$ & $146.4 \pm 70.0$ & $0.4 \pm 0.07$ & $0.3 \pm 0.03$ & $0.7 \pm 0.06$ \\
\hline
\end{tabular}

\subsection{Statistical Analyses}

For each variable, a two-way analysis of variance (ANOVA) was carried out to determine the effects of genotype, $\mathrm{N}$, and genotype $\mathrm{X} \mathrm{N}$ interaction to a significance of $p=0.05$ using JMP 13.0 software. Mean separations were performed by the Tukey-Kramer honest significant difference (HSD) test at $p=0.05$.

\section{Results}

\subsection{Pot Experiment}

$\mathrm{N}$ fertilization had a visible effect on plant growth and morphology. In the low $\mathrm{N}$ treatments $\left(10,20 \mathrm{mg} \mathrm{L}^{-1}\right)$, there were overt $\mathrm{N}$ deficiency symptoms, including the yellowing and narrowing of leaves (not shown). There was also clear stunting of growth compared to higher $\mathrm{N}$ treatments (Figure 2).

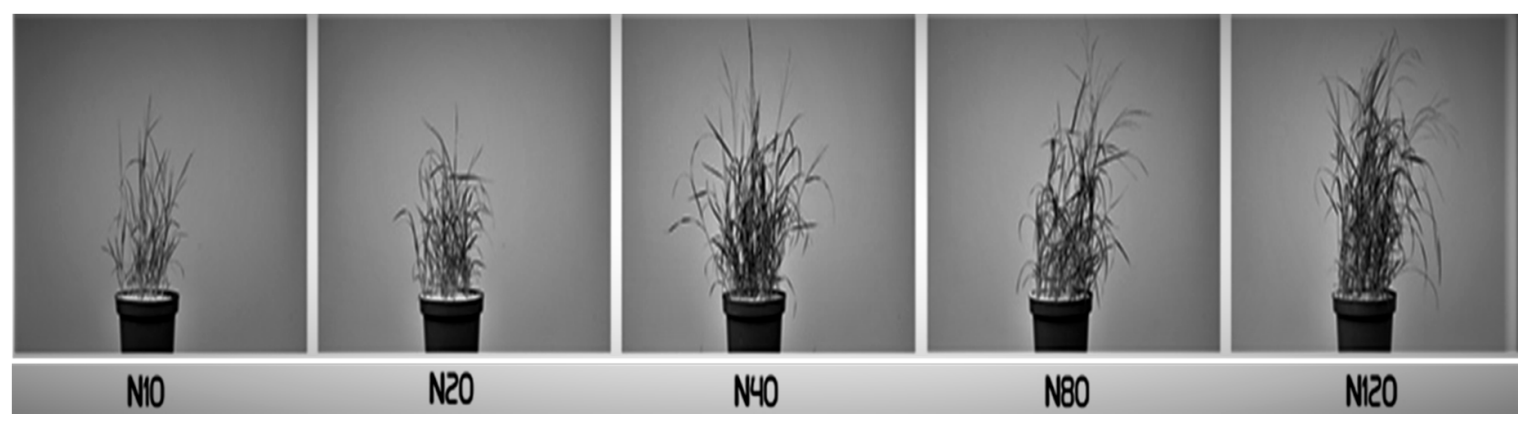

Figure 2. Response of tef leaves to different $\mathrm{N}$ fertilizer rates. N10-N120 indicates the concentration of $\mathrm{N}$ in irrigation solution (10-120 $\mathrm{mg} \mathrm{L}^{-1}$ ) in increasing order from left to right. 
ANOVA carried out for the pot experiment data revealed highly significant effects of genotype $(G)$ and $\mathrm{N}$ fertigation treatment $(\mathrm{N})$ on most variables reflecting plant productivity, mineral concentrations and minerals uptake, whereas $\mathrm{G} \times \mathrm{N}$ interaction was generally not significant (Tables S1 and S2). Five exceptions that exhibited significant interaction were the shoot dry weight, root dry weight, grain $\mathrm{N}$ concentration, total aboveground $\mathrm{N}$ uptake and grain $\mathrm{P}$ concentration. Although the $\mathrm{G} \times \mathrm{N}$ effects on these variables were significant, the trends of the effect were similar (Figures $3 \mathrm{~A}, \mathrm{C}$ and $4 \mathrm{~B}, \mathrm{C}, \mathrm{E}$ ). For the sake of simplicity, only the main effects are indicated in Figures 3 and 4, and for the sake of completion, the full ANOVA is presented in Tables S1 and S2.
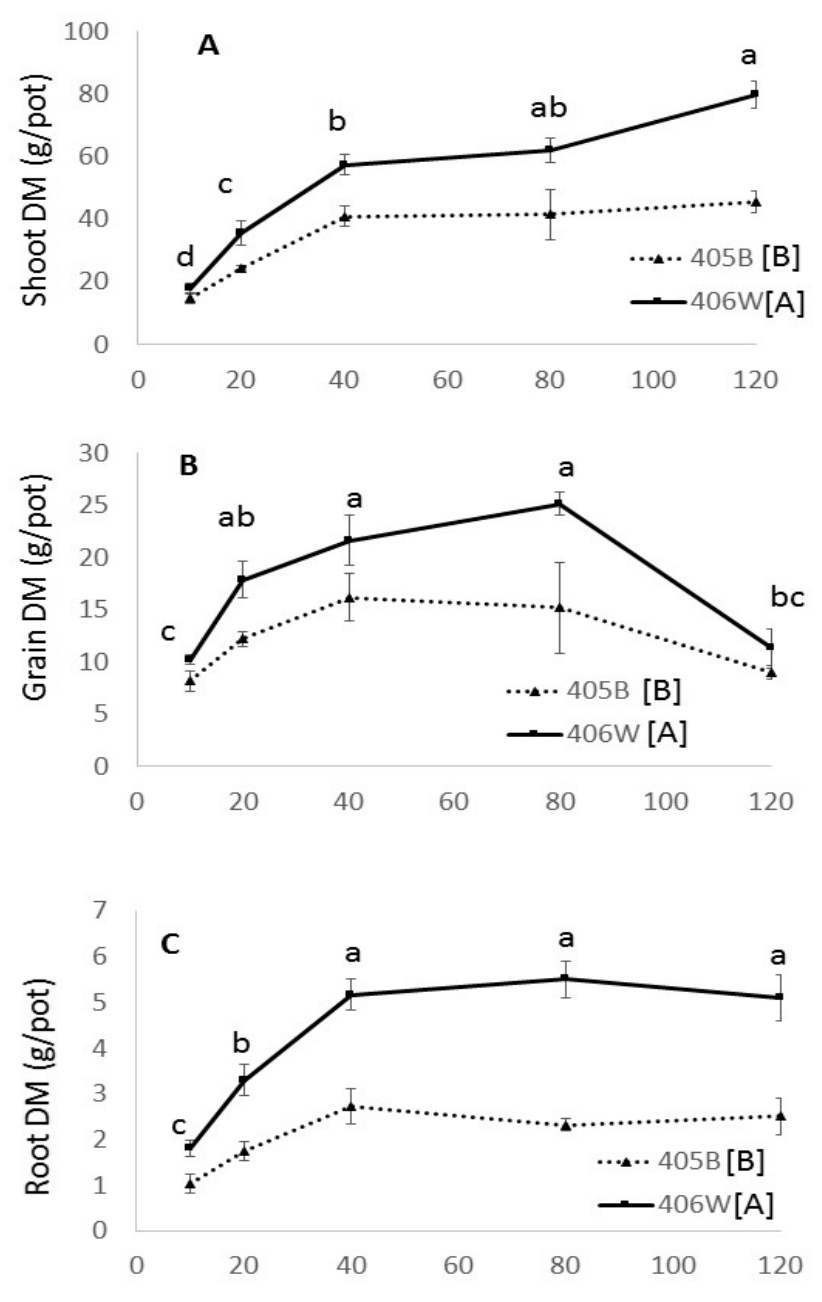

Concentration of $\mathrm{N}$ in irrigation water $\left(\mathrm{mg} \mathrm{L}^{-1}\right)$

Figure 3. Shoot (A), grain (B) and root (C) dry matter in the winter pot experiment by $\mathrm{N}$ fertigation level. Dashed line represents the 405B genotype, and solid line represents the $406 \mathrm{~W}$ genotype. Different letters represent significant $(<0.05)$ differences for both main effects. Lower case letters adjacent to the trend line represent the results of the Tukey's test for $\mathrm{N}$ concentration averaging both genotypes, and capital letters adjacent to the legend represent the results of the Student's $t$-test for the two different genotypes. 


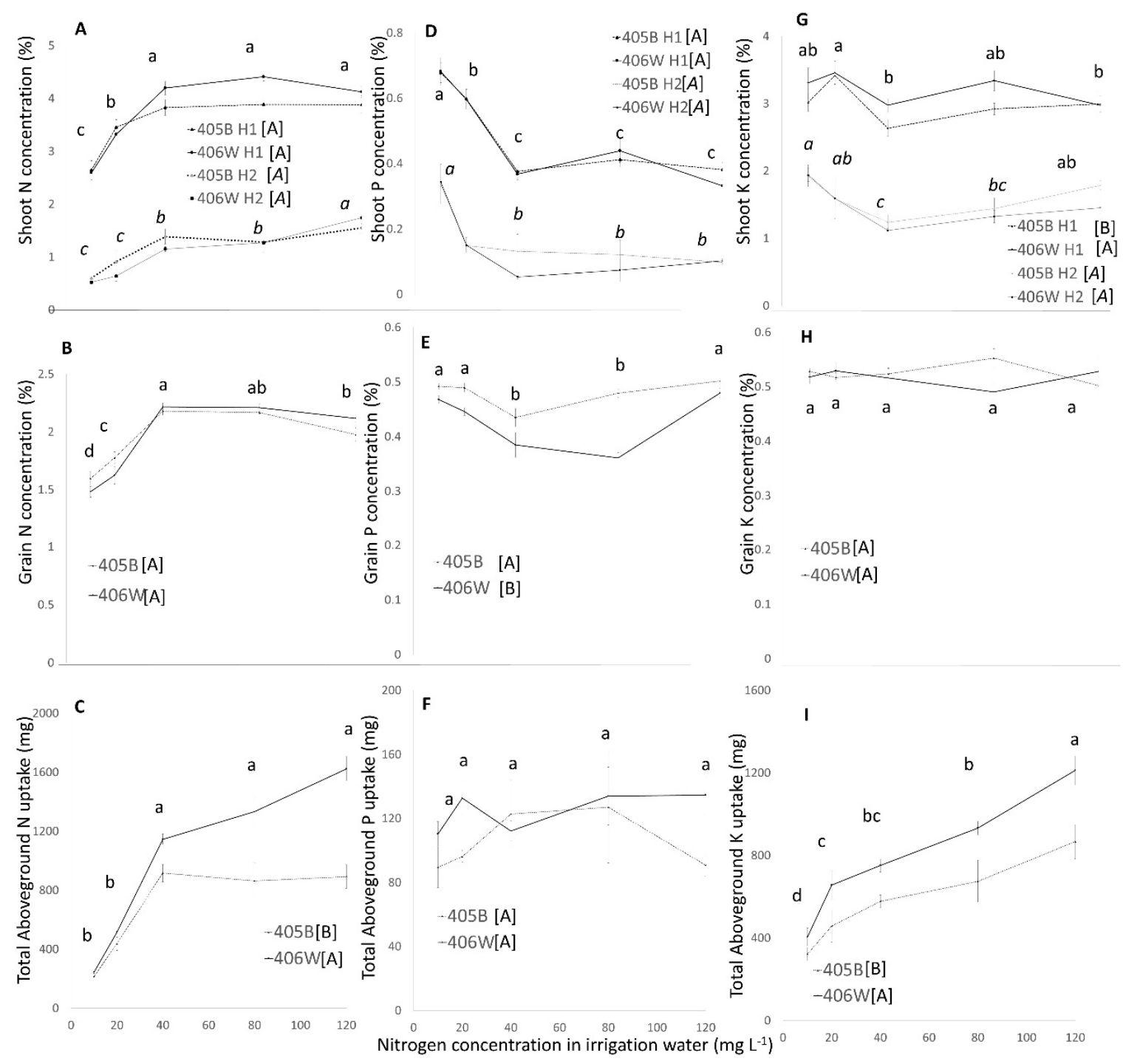

Figure 4. Shoot concentration (A,D,G), Grain concentration $(\mathrm{B}, \mathrm{E}, \mathrm{H})$, and total aboveground uptake $(\mathbf{C}, \mathbf{F}, \mathbf{I})$ of N, P, K (respectively) in the winter pot experiment. Dashed line represents the 405B genotype, and solid line represents the $406 \mathrm{~W}$ genotype. Shoot concentration $(\mathrm{A}, \mathrm{E}, \mathrm{G})$ was measured two times. In parts $(\mathbf{A}, \mathbf{D}, \mathbf{G})$, the first harvest (at flowering) is represented by black lines and straight letters, and the second harvest (at grain ripening) is represented by gray lines and italicized letters. Different letters represent significant $(<0.05)$ differences for both main effects. Letters adjacent to the trend line represent the results of Tukey's test for $\mathrm{N}$ concentration averaging both genotypes, and letters adjacent to the legend represent the results of the Student's $t$-test for the two different genotypes.

Significant differences were observed between the two genotypes in the various growth variables measured in this pot experiment. Genotype 406W grew taller (Table 2), with more dry matter in the shoot, root, and grain (Figure 3A-C), while 405B produced more tillers and flowered earlier (Table 2). There were no significant differences between the two genotypes in panicle length, harvest index, or SPAD measurements (Table 2). 
Table 2. Effect of $\mathrm{N}$ fertigation levels on growth parameters in the winter pot experiment.

\begin{tabular}{|c|c|c|c|c|c|c|c|c|}
\hline & $\begin{array}{l}\text { Nitrogen Treatment } \\
\left(\mathrm{mg} \mathrm{L}^{-1}\right)\end{array}$ & $\begin{array}{l}\text { Height } \\
\text { (cm) }\end{array}$ & $\begin{array}{c}\text { Panicle } \\
\text { Length }(\mathrm{cm})\end{array}$ & $\begin{array}{l}\text { Days to } \\
\text { Flowering }\end{array}$ & $\begin{array}{l}\text { Harvest } \\
\text { Index }\end{array}$ & SPAD & \# of Tillers & $\begin{array}{l}\text { Lodging } \\
\text { Index }\end{array}$ \\
\hline \multirow{5}{*}{$\begin{array}{l}\text { Genotype } \\
405 B\end{array}$} & 10 & 38.6 & 36 & 49.8 & 0.35 & 28.6 & 6.1 & 1.2 \\
\hline & 20 & 43.5 & 38 & 48.4 & 0.3 & 32.2 & 7.3 & 1.3 \\
\hline & 40 & 45.9 & 40.6 & 47 & 0.29 & 40.6 & 10.2 & 1.9 \\
\hline & 80 & 44.7 & 40.4 & 46 & 0.27 & 40.9 & 9.9 & 2.7 \\
\hline & 120 & 45.6 & 37.6 & 44 & 0.16 & 41.2 & 12.8 & 2.1 \\
\hline \multirow{5}{*}{$\begin{array}{l}\text { Genotype } \\
406 \mathrm{~W}\end{array}$} & 10 & 55.3 & 31 & 57 & 0.36 & 29.2 & 2.7 & 1.5 \\
\hline & 20 & 58.7 & 37.2 & 55.2 & 0.33 & 30.5 & 4.2 & 1.6 \\
\hline & 40 & 60 & 37.8 & 53.8 & 0.28 & 38.1 & 5.5 & 1.9 \\
\hline & 80 & 57 & 40.6 & 52.6 & 0.28 & 38.7 & 5.4 & 2.4 \\
\hline & 120 & 60.7 & 38.8 & 52.2 & 0.13 & 38.9 & 7.8 & 2.1 \\
\hline \multirow{5}{*}{$\begin{array}{l}\text { Tukey for } \\
\text { N } \\
\text { treatments }\end{array}$} & 10 & $46.9 \mathrm{~B}$ & $33.5 \mathrm{~B}$ & $53.4 \mathrm{~A}$ & $0.35 \mathrm{~A}$ & $28.9 \mathrm{C}$ & $4.4 \mathrm{D}$ & $1.4 \mathrm{C}$ \\
\hline & 20 & $51.1 \mathrm{~A}$ & $37.6 \mathrm{AB}$ & $51.8 \mathrm{AB}$ & $0.32 \mathrm{~A}$ & $31.4 \mathrm{~B}$ & $5.7 \mathrm{C}$ & $1.4 \mathrm{C}$ \\
\hline & 40 & $52.9 \mathrm{~A}$ & $39.2 \mathrm{~A}$ & $50.4 \mathrm{BC}$ & $0.28 \mathrm{~A}$ & $39.3 \mathrm{~A}$ & $7.8 \mathrm{~B}$ & $1.9 \mathrm{BC}$ \\
\hline & 80 & $50.8 \mathrm{~A}$ & $40.5 \mathrm{~A}$ & $49.3 \mathrm{C}$ & $0.28 \mathrm{~A}$ & $39.9 \mathrm{~A}$ & $7.6 \mathrm{~B}$ & $2.6 \mathrm{~A}$ \\
\hline & 120 & $53.1 \mathrm{~A}$ & $38.2 \mathrm{~A}$ & $48.1 \mathrm{C}$ & $0.15 \mathrm{~B}$ & $30.1 \mathrm{~A}$ & $10.3 \mathrm{~A}$ & $2.1 \mathrm{AB}$ \\
\hline \multirow{2}{*}{$\begin{array}{l}\text { Tukey for } \\
\text { genotype }\end{array}$} & $405 B$ & $47.0 \mathrm{~b}$ & $38.5 \mathrm{a}$ & $47.0 \mathrm{~b}$ & $0.28 \mathrm{a}$ & $36.7 \mathrm{a}$ & $9.3 \mathrm{a}$ & $1.8 \mathrm{a}$ \\
\hline & 406W & $54.1 \mathrm{a}$ & $37.1 \mathrm{a}$ & $54.1 \mathrm{a}$ & $0.27 \mathrm{a}$ & $35.1 \mathrm{~b}$ & $5.1 \mathrm{~b}$ & $1.9 \mathrm{a}$ \\
\hline $\begin{array}{c}\mathrm{N} \times \\
\text { genotype }\end{array}$ & N.S. & N.S. & N.S. & N.S. & N.S. & N.S. & N.S. & N.S. \\
\hline
\end{tabular}

Different letters represent significant $(<0.05)$ differences for both main effects. N.S. stands for non-significant.

\# the number of tillers.

The responses of both genotypes to increased $\mathrm{N}$ fertilization were similar. Between the $10 \mathrm{mg} \mathrm{L}^{-1}$ and the $40 \mathrm{mg} \mathrm{L}^{-1} \mathrm{~N}$ treatments, both genotypes displayed sharp increases in the shoot, root, and grain biomass (Figure $3 \mathrm{~A}-\mathrm{C}$ ), number of tillers, panicle length, plant height and SPAD values (Table 2), as well as a significantly decreased the number of days to flowering (Table 2).

The benefit of increased $\mathrm{N}$ concentrations was less obvious above $40 \mathrm{mg} \mathrm{L}^{-1}$. Between 40 and $120 \mathrm{mg} \mathrm{L}^{-1}$, the dry shoot matter rose significantly in genotype 406W, but not in 405B (Figure 3A), whereas there was no significant increase in root dry matter in either genotype. Interestingly, while there were no significant changes in grain yield between 40 and $80 \mathrm{mg} \mathrm{L}^{-1} \mathrm{~N}$, the $120 \mathrm{mg} \mathrm{L}^{-1} \mathrm{~N}$ treatment showed significantly lower grain yield in both genotypes (Figure 3B), which led to a significant decrease in the harvest index (Table 2). Between 40 and $120 \mathrm{mg} \mathrm{L}^{-1} \mathrm{~N}$ treatments, there was no change in plant height, panicle length and SPAD values, but there was an increase in the number of tillers and a decrease in days to flowering (Table 2).

In both genotypes, the lodging index rose as the $\mathrm{N}$ concentration rose in the irrigation water from $10-80 \mathrm{mg} \mathrm{L}^{-1}$ (Table 2). There is a slight fall in the degree of lodging in the $120 \mathrm{mg} \mathrm{L}^{-1} \mathrm{~N}$ treatment, possibly due to the decrease in grain yield.

The $\mathrm{N}$ concentration in the shoot was measured twice over the course of the experiment. The response of $\mathrm{N}$ concentrations in the shoot to $\mathrm{N}$ concentrations in the irrigation water was similar for both genotypes, with differences between harvests (Figure 4A). In the first measurement, which was taken at flowering time, the $\mathrm{N}$ concentration was very high (2.6-4.4\%). In this harvest, there was a sharp increase in $\mathrm{N}$ concentration in the shoot as the $\mathrm{N}$ concentration in the irrigation water rose from $10-40 \mathrm{mg} \mathrm{L}^{-1} \mathrm{~N}$. However, there was no significant impact on the shoot $\mathrm{N}$ concentration when the $\mathrm{N}$ treatment rose from $40-120 \mathrm{mg} \mathrm{L}^{-1}$.

In the second harvest (at maturity), the $\mathrm{N}$ concentration was much lower (0.5-1.7\%) (Figure 4A). The $\mathrm{N}$ concentration in the shoot rose between 10 and $40 \mathrm{mg} \mathrm{L}^{-1}$, and there was another small increase between 80 and $120 \mathrm{mg} \mathrm{L}^{-1}$.

In both genotypes, the concentration of $\mathrm{N}$ in the grain rose as the $\mathrm{N}$ concentration in the irrigation water rose from $10-40 \mathrm{mg} \mathrm{L}^{-1}$ by $47 \%$ (Figure $4 \mathrm{~B}$ ). In higher $\mathrm{N}$ treatments, the $\mathrm{N}$ concentration in the grain exhibited a minor decrease.

The aboveground $\mathrm{N}$ uptake (Figure $4 \mathrm{C}$ ) is the product of grain and shoot biomass and the $\mathrm{N}$ concentration in both these plant segments. As such, it tracks the changes in both these factors. Between 
10 and $40 \mathrm{mg} \mathrm{L}^{-1} \mathrm{~N}$, where the biomass and $\mathrm{N}$ concentration in the shoot and grain rose, the total $\mathrm{N}$ uptake in the shoot rose by a factor of 4.5 . Between 40 and $120 \mathrm{mg} \mathrm{L}^{-1}$, where there were smaller rises in biomass in the shoot, and biomass and $\mathrm{N}$ concentration in the grain decreased, the total aboveground $\mathrm{N}$ uptake did not rise significantly when averaged across the two genotypes, although there was a trend towards greater aboveground $\mathrm{N}$ uptake in the higher $\mathrm{N}$ treatments in the 406W genotype.

The $\mathrm{N}$ concentration in the irrigation water also affected the $\mathrm{P}$ concentration in the shoot and grain (Figure 4D,E). As N increased from 10-40 $\mathrm{mg} \mathrm{L}^{-1}$, the $P$ concentration in the shoot fell in both the first and second harvest. From $40-120 \mathrm{mg} \mathrm{L}^{-1} \mathrm{~N}$, there was no further change in P concentration in the shoot in either harvest. The $\mathrm{P}$ in the grain exhibited small but statistically significant differences between $\mathrm{N}$ treatments. As $\mathrm{N}$ increased from $10-40 \mathrm{mg} \mathrm{L}^{-1}, \mathrm{P}$ concentration fell by $12 \%$ in the 405B genotype but rose at $80-120 \mathrm{mg} \mathrm{L}^{-1}$. In the $406 \mathrm{~W}$ genotype, the $\mathrm{P}$ concentration fell by $23 \%$ between 10 and $80 \mathrm{mg} \mathrm{L}^{-1} \mathrm{~N}$ and recovered at $120 \mathrm{mg} \mathrm{L}^{-1}$. These slightly different trends are reflected in a significant NxG interaction (Table S2). Whereas the concentration of $\mathrm{P}$ in the shoot in harvest 1 and 2 was strongly affected by the $\mathrm{N}$ treatments, the total $\mathrm{P}$ uptake into the aboveground biomass was not significantly affected (Figure $4 \mathrm{~F}$ ).

The $\mathrm{N}$ concentration in the irrigation water did not seem to affect $\mathrm{K}$ concentration in the shoot (Figure 4G). In both harvests, there were some small statistically significant differences between the $\mathrm{N}$ treatments with no clear pattern, and the K concentration changed seemingly haphazardly as the $\mathrm{N}$ levels in the irrigation water rise. The $\mathrm{K}$ concentration in the grain was a constant $0.5 \%$, regardless of the $\mathrm{N}$ treatment or the genotype (Figure $4 \mathrm{H}$ ). The increase in biomass that was recorded in response to an increase of $\mathrm{N}$ in the irrigation water, coupled with the static response of the $\mathrm{K}$ concentration in the shoot and grain, means that the $\mathrm{K}$ uptake to these organs was significantly increased by a factor of 3 (Figure 3I) as the $\mathrm{N}$ in the irrigation water increased from 10 to $120 \mathrm{mg} \mathrm{L}^{-1}$.

\subsection{Field Experiment}

ANOVA carried out for the field experiment data revealed significant effects of genotype $(G)$ and $\mathrm{N}$ fertigation treatment $(\mathrm{N})$ on some variables reflecting plant productivity and tissue nutrient concentrations, whereas $\mathrm{G} \times \mathrm{N}$ interaction was not significant (Tables S3 and S4).

There were significant differences observed between the two genotypes in the growth variables measured in this experiment. Unlike the winter pot experiment where 406W had larger shoot biomass and grain yield, in this experiment, 405B produced similar shoot biomass (Figure 5A) and greater grain yield (Figure $5 \mathrm{~B}$ ). It also had a significantly larger harvest index (Table 3 ) and a shorter vegetative stage (Table 3). There was a trend, although not statistically significant that 405B had on average 3.4 more tillers. There were no significant differences between the two genotypes in panicle length or SPAD measurements (Table 3).

The responses of the tef in most variables to increased $\mathrm{N}$ fertilization in the field showed a similar trend to those recorded in the winter pot experiment; however, the responses in the field were often not statistically significant (Table 3). The plants displayed significant increases in grain yield between the $0 \mathrm{mg} \mathrm{L}^{-1}$ treatment and the $60 \mathrm{mg} \mathrm{L}^{-1}$ treatment, and minor (non-significant) increases in shoot dry matter in the same range (Figure $5 \mathrm{~A}, \mathrm{~B}$ ). Non-significant trends towards a greater number of tillers and panicle length and earlier flowering were measured throughout the entire range of $\mathrm{N}$ fertilization (0-120 mg L ${ }^{-1} \mathrm{~N}$ ) (Table 3). Unlike the winter pot experiment, in the summer field experiment, plant height was not affected by $\mathrm{N}$ fertilization level.

The $\mathrm{N}$ concentrations in the shoot at flowering in the summer field experiment were slightly higher than those of the second field harvest (Figure 6A,B) and were relatively low compared to the winter pot experiment (Figure $4 \mathrm{~A}$ ). With increasing $\mathrm{N}$ fertilization, the $\mathrm{N}$ concentration in the shoot rose rather steeply between 0 and $60 \mathrm{mg} \mathrm{L}^{-1}$, and then more gradually between 60 and $120 \mathrm{mg} \mathrm{L}^{-1}$ (Figure 6A,B), whereas the $\mathrm{N}$ concentration in the grain did not seem to rise beyond $30 \mathrm{mg} \mathrm{L}^{-1} \mathrm{~N}$ (Figure 6C). 
Unlike in the pot experiment, all the plants in the field experiment were lodged by the time of grain maturity (data not shown).
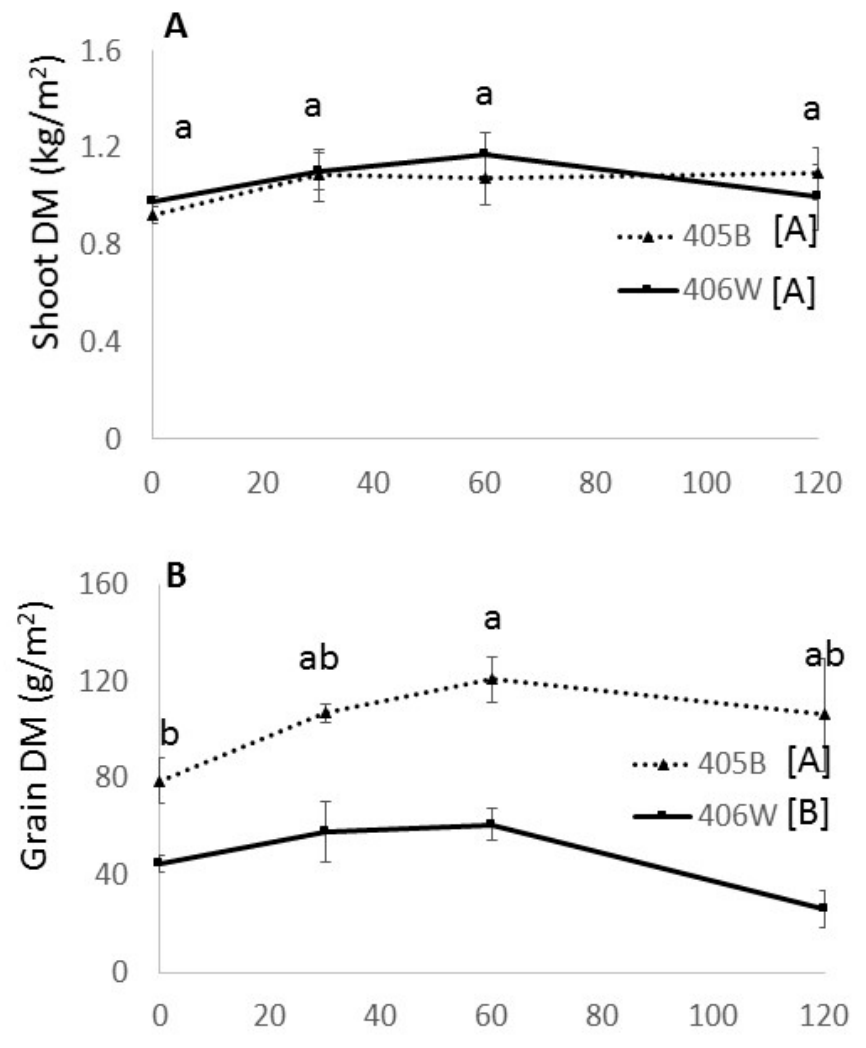

Concentration of $\mathrm{N}$ in irrigation water $\left(\mathrm{mg} \mathrm{L}^{-1}\right)$

Figure 5. Shoot (A) and grain (B) dry matter in the summer field experiment by $\mathrm{N}$ fertigation level. Dashed line represents the 405B genotype, and solid line represents the 406W genotype. Different letters represent significant $(<0.05)$ differences for both main effects. Letters adjacent to the trend line represent the results of the Tukey's test for $\mathrm{N}$ concentration averaging both genotypes, and letters adjacent to the legend represent the results of the Student's $t$-test for the two different genotypes.

Table 3. Effect of $\mathrm{N}$ fertigation levels on growth parameters in the summer field experiment.

\begin{tabular}{|c|c|c|c|c|c|c|c|}
\hline & $\begin{array}{l}\text { Nitrogen Treatment } \\
\left(\mathrm{mg} \mathrm{L}^{-1}\right)\end{array}$ & $\begin{array}{l}\text { Height } \\
\text { (cm) }\end{array}$ & $\begin{array}{l}\text { Panicle Length } \\
\text { (cm) }\end{array}$ & $\begin{array}{l}\text { Days to } \\
\text { Flowering }\end{array}$ & $\begin{array}{l}\text { Harvest } \\
\text { Index }\end{array}$ & SPAD & $\begin{array}{c}\text { \# of } \\
\text { Tillers }\end{array}$ \\
\hline \multirow{4}{*}{$\begin{array}{l}\text { Genotype } \\
405 \mathrm{~B}\end{array}$} & 0 & 100.9 & 29.4 & 41 & 0.08 & 31.7 & 8.2 \\
\hline & 30 & 95.8 & 29.8 & 38.6 & 0.09 & 34.9 & 11.6 \\
\hline & 60 & 100.7 & 33.1 & 37.4 & 0.1 & 37.3 & 13.8 \\
\hline & 120 & 99.2 & 28.7 & 36.6 & 0.09 & 36.4 & 16.4 \\
\hline \multirow{4}{*}{$\begin{array}{l}\text { Genotype } \\
406 \mathrm{~W}\end{array}$} & 0 & 89.9 & 26.7 & 59.2 & 0.04 & 33.5 & 5.4 \\
\hline & 30 & 104.4 & 25.1 & 55 & 0.05 & 33.4 & 6.8 \\
\hline & 60 & 94.6 & 34.6 & 56.4 & 0.05 & 37.3 & 11.2 \\
\hline & 120 & 95.4 & 25.8 & 55 & 0.03 & 40.5 & 13 \\
\hline \multirow{4}{*}{$\begin{array}{l}\text { Tukey's for N } \\
\text { treatments }\end{array}$} & 0 & $95.4 \mathrm{~A}$ & $28.1 \mathrm{~A}$ & $50.1 \mathrm{~A}$ & $0.06 \mathrm{~A}$ & $31.6 \mathrm{C}$ & $6.8 \mathrm{~A}$ \\
\hline & 30 & $100.1 \mathrm{~A}$ & $27.5 \mathrm{~A}$ & $46.8 \mathrm{~A}$ & $0.07 \mathrm{~A}$ & $34.1 B C$ & $9.2 \mathrm{~A}$ \\
\hline & 60 & $97.7 \mathrm{~A}$ & $33.9 \mathrm{~A}$ & $46.9 \mathrm{~A}$ & $0.08 \mathrm{~A}$ & $37.3 \mathrm{AB}$ & $12.5 \mathrm{~A}$ \\
\hline & 120 & $97.3 \mathrm{~A}$ & $27.3 \mathrm{~A}$ & $45.8 \mathrm{~A}$ & $0.06 \mathrm{~A}$ & $38.4 \mathrm{~A}$ & $14.7 \mathrm{~A}$ \\
\hline \multirow{2}{*}{$\begin{array}{l}\text { Tukey's for } \\
\text { genotype }\end{array}$} & 405B & $99.1 \mathrm{a}$ & $30.3 a$ & $38.4 \mathrm{~b}$ & $0.09 \mathrm{a}$ & $35.1 \mathrm{a}$ & $12.5 \mathrm{a}$ \\
\hline & 406W & $96.1 \mathrm{a}$ & $28.1 \mathrm{a}$ & $56.4 \mathrm{a}$ & $0.04 \mathrm{~b}$ & $35.7 \mathrm{a}$ & $9.1 \mathrm{a}$ \\
\hline $\mathrm{N} \times$ genotype & N.S. & N.S. & N.S. & N.S. & N.S. & N.S. & N.S. \\
\hline
\end{tabular}



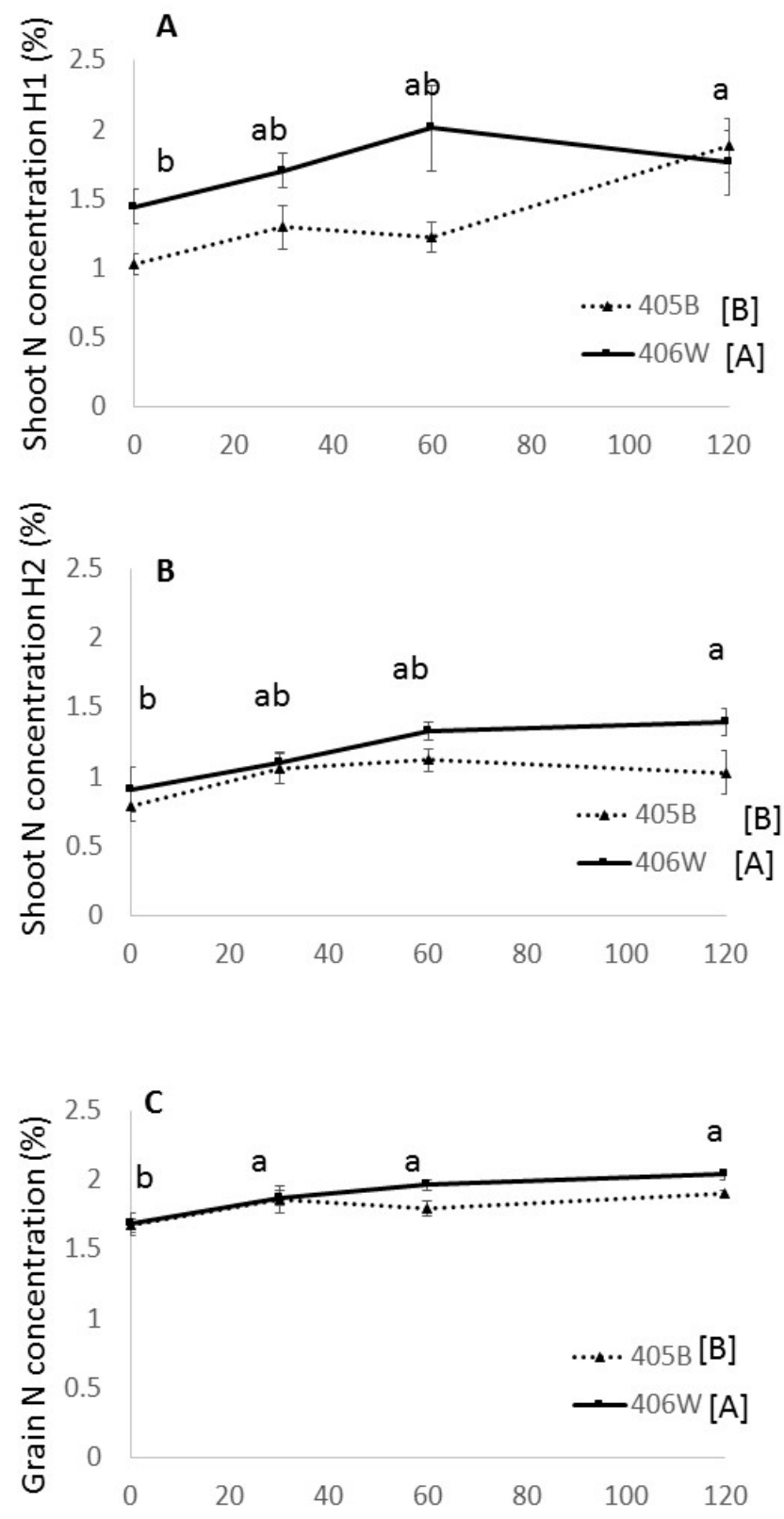

\section{Concentration of $\mathrm{N}$ in irrigation water $\left(\mathrm{mg} \mathrm{L}^{-1}\right)$}

Figure 6. Shoot $\mathrm{N}$ concentration at flowering (A), grain ripening (B) and grain $\mathrm{N}$ concentration (C) in the summer field experiment. Dashed line represents the 405B genotype, and solid line represents the 406W genotype. Different letters represent significant $(<0.05)$ differences for both main effects. Letters adjacent to the trend line represent the results of Tukey's test for $\mathrm{N}$ concentration averaging both genotypes, and letters adjacent to the legend represent the results of the Student's $t$-test for the two different genotypes.

Increased $\mathrm{N}$ decreased the $\mathrm{P}$ concentration in the shoot (Figure 7A), but there was no clear effect of $\mathrm{N}$ fertilization on $\mathrm{K}$ concentration in the shoot (Figure 7B). 

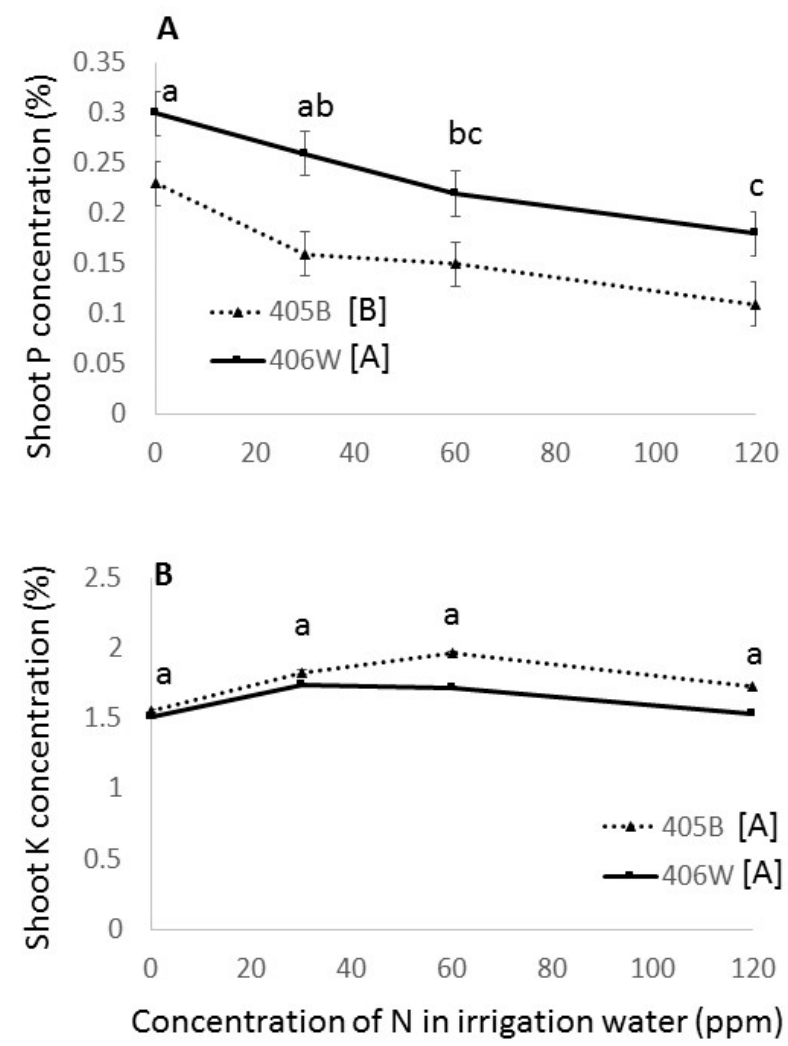

Figure 7. Shoot concentration of $\mathrm{P}(\%)(\mathbf{A})$ and $\mathrm{K}(\%)(\mathbf{B})$ at harvest in the summer field experiment. Dashed line represents the 405B genotype, and solid line represents the $406 \mathrm{~W}$ genotype. Different letters represent significant $(<0.05)$ differences for both main effects. Letters adjacent to the trend line represent the results of the Tukey's test for $\mathrm{N}$ concentration averaging both genotypes, and letters adjacent to the legend represent the results of the Student's $t$-test for the two different genotypes.

\section{Discussion}

The primary purpose of this study was to elucidate the rudimentary response of tef to $\mathrm{N}$ nutrient availability. To this end, two complementary experiments were conducted (i) a pot experiment conducted during winter in plastic-covered tunnels, in which the use of perlite as growth medium eliminated any possible influences of local soil properties, and (ii) an open field experiment conducted during summer. In both experiments, a fertigation system ensured precisely managed levels of $\mathrm{N}$ application. The use of two diverse tef genotypes in both experiments was intended to represent some of the substantial genetic diversity that characterizes this species [39].

\subsection{Pot Experiment}

Agronomic properties of various tef genotypes were characterized by Bedane et al. [40] under conditions similar to our pot experiment, i.e., growing tef in pots in a covered environment during winter with relatively short days $(10.5 \mathrm{~h})$. Many of the measurements that they took were comparable to those measured in our experiment, including the plant height $(37-69 \mathrm{~cm}$ vs. $40-60 \mathrm{~cm}$ ), panicle length (23-43 cm vs. $40 \mathrm{~cm}$, number of tillers per plant (3.7-13.3 tiles vs. 5-12 tillers), and harvest index (8-28\% vs. 13-27\%), in Bedane et al. [40] vs. our well-fertilized treatments, respectively. Our plants reached $50 \%$ flowering fairly early (45-55 days after sowing) compared to $50-80$ days reported by Bedane et al. [40].

The response of the tef plants to $\mathrm{N}$ fertilization in the pot experiment can be divided into 3 sections: underfertilization (10-40 $\mathrm{mg} \mathrm{L}^{-1} \mathrm{~N}$ ), sufficient fertilization $\left(40-80 \mathrm{mg} \mathrm{L}^{-1}\right)$, and overfertilization (80-120 $\left.\mathrm{mg} \mathrm{L}^{-1}\right)$. The most pronounced changes due to $\mathrm{N}$ fertilization occurred in the underfertilization range. At the low end of this section, there were overt $\mathrm{N}$ deficiency symptoms, including the yellowing 
and narrowing of leaves (not shown) and the clear stunting of growth (Figure 2). As $\mathrm{N}$ fertilization was increased from 10 to $40 \mathrm{mg} \mathrm{L}^{-1}$, we observed an increase in $\mathrm{N}$ uptake, $\mathrm{N}$ concentration in shoot and grain, biomass, grain yield, panicle length, plant height, and the number of tillers (Table 2, Figures 3 and $4 \mathrm{~A}, \mathrm{~B}$ ). In addition, over that range, we observed a decrease in days to flowering (Table 2) and $\mathrm{P}$ concentration (Figure 4D,E). Taken together, these observations paint a picture of plants whose growth was mainly limited by $\mathrm{N}$ deficiency and which could be greatly enhanced by increasing $\mathrm{N}$ fertilization.

Not only grain quantity was affected by increased $\mathrm{N}$ fertilization in the $10-40 \mathrm{mg} \mathrm{L}^{-1} \mathrm{~N}$ range, but the grain quality as well, since the concentration of $\mathrm{N}$ in the grain is directly related to the protein content [41]. Increases in grain protein in tef due to increased $\mathrm{N}$ fertilization were also observed by Habtegebrial and Singh [26], Giday et al. [42], and Dagnaw [43]. Paff and Asseng [44] reviewed existing data and found that at low $\mathrm{N}$, increasing $\mathrm{N}$ availability led to increased $\mathrm{N}$ concentration in the grain, though excess $\mathrm{N}$ fertilization sometimes caused grain $\mathrm{N}$ concentration to level off or decrease due to lodging or luxury uptake.

We measured a small but statistically significant decrease in the number of days to flowering due to increased $\mathrm{N}$ availability (Table 2). This phenomenon has been reported in other cereals such as wheat [45] and sorghum [46], and maize [47,48], although nitrogen fertilization has also been shown to delay maturity in barley [49] and rice [50]. A meta-analysis of 1130 papers on barley and wheat indicated that flowering time was not generally affected by $\mathrm{N}$ availability in these two species [51].

The decline in $\mathrm{P}$ concentration as $\mathrm{N}$ increased in the $10-40 \mathrm{mg} \mathrm{L}^{-1}$ range, observable both in the early stages of growth and at the final harvest (Figure 4D), requires some explanation. The simplest explanation is that the $\mathrm{P}$ was diluted as the plant grew bigger with increased $\mathrm{N}$, as $\mathrm{P}$ uptake does not change as $\mathrm{N}$ increases. Even though $\mathrm{P}$ concentration decreased with increased $\mathrm{N}$ from $10-40 \mathrm{mg} \mathrm{L}^{-1}$, it seems that this did not lead to P deficiency. In another part of this experiment, which was not reported here but was written up as a Masters thesis [52], when $P$ fertilization was increased from $6 \mathrm{mg} \mathrm{L}^{-1}$ to $12 \mathrm{mg} \mathrm{L}^{-1}$ and $\mathrm{N}$ was kept at a constant $40 \mathrm{mg} \mathrm{L}^{-1}$, the $\mathrm{P}$ concentration in the leaf increased up from $0.37 \%$ to $0.58 \%$, which is similar to the $\mathrm{P}$ concentration in the low $\mathrm{N}$ treatments reported in this paper (Figure 4D). However, high $\mathrm{P}$ application had no discernable positive impact on the plant, and in fact, it severely lowered the grain yield [52].

In contrast to $\mathrm{P}, \mathrm{K}$ uptake increased considerably with increasing $\mathrm{N}$ concentration in the irrigation water (Figure 4I), leading to a fairly constant $\mathrm{K}$ concentration in the shoot even as the plants grew bigger. This suggests that increased $\mathrm{N}$ concentration caused an increase in $\mathrm{K}$ demand in the plant, thus emphasizing the need for balanced fertilization in tef. This is particularly important in light of the fact that $\mathrm{K}$ fertilization is often not supplied to tef fields in Ethiopia $[53,54]$, a practice which has been challenged following recent field experiments and large scale studies $[53,55,56]$.

Unlike the underfertilization range, in the sufficient fertilization range $\left(40-80 \mathrm{mg} \mathrm{L}^{-1} \mathrm{~N}\right)$, increasing concentrations of fertigated $\mathrm{N}$ had no effect on most growth variables since the plant already had sufficient $\mathrm{N}$ for growth. Plant height, panicle length, leaf $\mathrm{N}$ concentration, $\mathrm{N}$ uptake, biomass, grain yield and grain $\mathrm{N}$ concentration were not affected within this range (Figures 3 and 4, Table 2). Leaf $\mathrm{P}$ concentration did not fall, probably due to the fact that the biomass did not rise, so no dilution occurred (Figure 4D). Overall, the results suggest that $\mathrm{N}$ was sufficiently available throughout this range for all plant functions. Nevertheless, the K uptake continued to rise with increased N (Figure 4I). Furthermore, lodging increased with increase $\mathrm{N}$ fertilization in this range (Table 2), indicating that even though within this range, grain and aboveground biomass are unaffected, increased $\mathrm{N}$ is not completely benign.

Between 80 and $120 \mathrm{mg} \mathrm{L}^{-1} \mathrm{~N}$, the plants reached a state of overfertilization. Added $\mathrm{N}$ had no effect in most variables in this range. No significant changes in height panicle length, shoot or root dry matter, $\mathrm{N}$ concentration in leaf or grain were recorded. The most dramatic changes in this range were the increase in tiller numbers, alongside a sharp decrease in grain production (Figures 3 and 4, Table 2). Overfertilization can reduce yield in two ways: (1) toxicity (osmatic or otherwise), (2) increasing vegetative growth at the expense of reproductive growth [57]. In this case, it seems that the decrease in grain production is not due to $\mathrm{N}$ toxicity, considering that we did see any significant 
increase in $\mathrm{N}$ concentration or a decrease in any other growth variables. Rather, it seems clear that the decrease in grain yield was caused by increased vegetative growth at the expense of reproductive growth. No increase in lodging was observed with increased $N$ in this range, suggesting that the decline in grain yield cannot be attributed to increased lodging (Table 2). A decrease in grain yield in tef plants subjected to overfertilization of $\mathrm{N}$ was also reported by Dagnaw [43]. Interestingly, this is not included in the models developed by Tesfahunegn [58], which assumed that grain yield becomes asymptotic once it reaches optimum nutrition.

\subsection{Field Experiment}

A subsequent open-field experiment was carried out during summer, aiming to validate the principle tef responses to fertigated $\mathrm{N}$ levels under commercial-like conditions and testing the possibility of growing tef in the hot, arid conditions of the Northern Negev Desert.

The results of our summer field experiment were mostly in line with the findings of the winter pot experiment, although many of the trends in the field experiment were not statistically significant. In both experiments, increased $\mathrm{N}$ fertigation, at least up to a certain point, was found to increase tillering (Tables 2 and 3), decrease the duration of the vegetative stage (Tables 2 and 3), increase shoot DM (Figures 3 and 5), increase $\mathrm{N}$ concentration and uptake in the shoot (Figures 4 and 7), no clear effect on $\mathrm{K}$ concentration (Figures $4 \mathrm{G}$ and $7 \mathrm{~B}$ ), and decrease in shoot $\mathrm{P}$ concentration (Figures $4 \mathrm{D}$ and 7A). Furthermore, increase $\mathrm{N}$ fertilization above the optimum range caused a decrease in grain yield (Figures 3B and 5B)

One weakness of this study is that the pot trial and the field trial were not repeated in different years or in different environments. It is possible that the plant response to $\mathrm{N}$ fertigation may have been different-in-different years or in different environments. Furthermore, the two experiments presented in this study are too different from each other to act as replications. It is unknowable if the differences between the two experiments stemmed from the experimental design (protected pots vs. field) or the season or something else entirely. Nonetheless, the fact that many of these findings were replicated in very different growth conditions somewhat reinforces the validity of our findings.

Some findings from the pot experiment were not confirmed in the field conditions, including the increased plant height and panicle length with increased $\mathrm{N}$ fertigation and continuously decreasing harvest index as $\mathrm{N}$ is increased (Table 3), both of which were observed only in the winter pot experiment (Table 2).

One of the most striking differences between the winter pot experiment and the summer field trial was the harvest index. Across the treatments, the winter pot experiment showed a mean HI of $27 \%$, which is within the range of harvest indexes for tef reported elsewhere [58-60]. In contrast, the mean $\mathrm{HI}$ across treatments in the summer field trial was 7\%. Although the aboveground biomass of 11.3 tons/ha was high compared to the values reported in the literature [58-60], the grain harvest of 0.75 ton/ha was much lower than the values reported in the literature [58-60]. Low $\mathrm{HI}$ has been previously reported for Israeli grown tef [61] and has major implications for the possibility of tef cultivation in the Northern Negev.

The low $\mathrm{HI}$ in the summer field experiment may be due to the long daylight hours in the summer in Israel (Figure 1). In its native equatorial Ethiopia, tef is not exposed to long days, even in the summer [61]. A study on the effect of day length on tef growth showed that increased daylight hours delay the induction of the reproductive stage [62]. Delayed induction of the reproductive stage could cause more vegetative growth and less reproductive growth; limiting the grain yield could explain the low harvest index. At the beginning of the summer field trial, the length of the day was $14 \mathrm{~h}$, and it slowly fell to between 12.5 and $13 \mathrm{~h}$ at the flowering stage (depending on the genotype) and down to $11.1 \mathrm{~h}$ at harvest. This is not necessarily an insurmountable obstacle to tef cultivation in the Northern Negev. Van Delden [62] concluded that some genotypes respond more strongly to long days than others and that it is possible to breed tef plants that are more suited for long day cultivation. Furthermore, cultivation in seasons with shorter days may be a possible solution, as was demonstrated 
by the higher $\mathrm{HI}$ in the winter pot experiment (Table 2). Ben-Zeev et al. [37] suggested that tef be planted in Israel between March and April, unlike the experiment reported here, which was planted in July. However, as mentioned above, their study also yielded low HI.

Another possible explanation for the low $\mathrm{HI}$ in the summer field trial is the high temperatures. Temperatures in the northern Negev were far in excess of typical Ethiopian growing conditions. Tef is generally grown below 27 degrees ${ }^{\circ} \mathrm{C}$ [62], with a daily average between $15{ }^{\circ} \mathrm{C}$ and $22{ }^{\circ} \mathrm{C}$. In our summer field experiment, the maximum temperatures experienced by the plant were between $30^{\circ} \mathrm{C}$ and $40{ }^{\circ} \mathrm{C}$. (Figure 1). This was true even towards the end of the experiment when the weather was somewhat cooler (Figure 1). Nevertheless, it may be possible to overcome these limitations. Ben Ze'ev et al. [37] stated that small-scale and commercial tef production in Israel had been shown to have a yield of approximately 3 tons of grain and 20 tons of biomass per hectare.

Defining an optimum range from $40-80 \mathrm{mg} \mathrm{L}^{-1} \mathrm{~N}$ in the irrigation water is a good starting point for the enhancement of tef production. Nevertheless, fertigation is still quite rare in Ethiopia, as well as worldwide. This range, which may be correct on a perlite growth medium, may become irrelevant on most natural soils due to interactions with soil minerals, water availability, and more. In contrast, plant $\mathrm{N}$ status at various growth stages appears a much better and direct indicator.

In the winter pot experiment, $\mathrm{N}$ concentration in shoots was much higher at the earlier stages of growth than at the later stages (Figure 4A), suggesting that $\mathrm{N}$ is taken up at the early stages of development is mobilized for later reproductive and vegetative growth. This phenomenon was previously reported in many different crops [63], although we are not aware of any reports of this phenomenon specifically in Tef. Based on this phenomenon, Lemaire et al. [63] and the works cited therein developed critical $\mathrm{N}$ dilution curves for different crops, which show how $\mathrm{N}$ concentration falls as biomass grows and what the minimum $\mathrm{N}$ concentration should be at any given growth stage in order to allow optimum growth.

Not much data exists about the optimum $\mathrm{N}$ concentration in tef at different growth stages. Paff and Asseng [44], in their review, reported a lack of data from tissue analysis at various growth stages as being a limitation on tef growth models. We do not have enough data to develop a critical dilution curve for tef as was done for other crops such as wheat [64], rapeseed [65], and rice [66]. However, it is interesting to look at the concentration of $\mathrm{N}$ in the flowering stage and relate it to the grain yield in an attempt to relate early $\mathrm{N}$ concentration to plant performance. In our winter pot experiment, the highest grain yield was found in plants that had a tissue $\mathrm{N}$ concentration at flowering between $3.7 \%$ and $4.4 \%$, depending on the genotype (Figure $4 \mathrm{~A}$ ). In the summer field experiment, the highest grain yield was found in plants that had a tissue concentration of $1.2-2 \%$ at flowering, depending on the genotype (Figure 6A). Future work could develop a critical $\mathrm{N}$ dilution for tef, using either data from existing experiments or setting up dedicated experiments that could be used to make $\mathrm{N}$ fertilization recommendations based on early plant tissue analysis. SPAD readings could also be used to make $\mathrm{N}$ recommendations, but caution is required since SPAD readings do not directly measure $\mathrm{N}$ content, and the relationship between $\mathrm{N}$ content and SPAD readings has been shown in other grains to vary due to genotype and environmental conditions [67]. Optimized $N$ fertilization practice for tef will improve tef yield and protein content, as well as avoid excess fertilizer application and consequent environmental degradation [24].

\section{Conclusions}

A number of important conclusions can be drawn from the winter pot experiment. First, optimum $\mathrm{N}$ fertigation concentration is between 40 and $80 \mathrm{mg} \mathrm{L}^{-1} \mathrm{~N}$, at which the time to flowering is low and yield and grain quality highest. Underfertilization caused a decrease in overall plant growth, whereas overfertilization caused an increase in vegetative growth at the expense of grain yield. $\mathrm{K}$ uptake increased along with increased $\mathrm{N}$ availability, emphasizing the need for balanced fertilization in tef. The field experiment showed that the basic plant response to $\mathrm{N}$ remained similar, even under very different conditions. Nevertheless, the fertilization rate will always need to take into account local soil 
and climate. The field experiment also pointed to low $\mathrm{HI}$ as a major limitation on tef cultivation in the Northern Negev. Changes in genotype and cultivation practices are suggested in order to overcome this limitation.

Supplementary Materials: The following are available online at http://www.mdpi.com/2073-4395/10/12/1870/s1, Table S1: Full Anova report for parameters in Table 2 from winter pot experiment Table S2: Full Anova report for parameters in Figures 3 and 4 from winter pot experiment Table S3: Full Anova report for parameters in Table 3 from summer field experiment. Table S4: Full Anova report for parameters in Figures 5-7 from summer field experiment.

Author Contributions: Conceptualization, K.G., A.B., Y.S. and U.Y.; Data curation, K.G.; Formal analysis, K.G.; Methodology, K.G., I.Z., Y.S. and U.Y.; Supervision, U.Y.; Writing—original draft, K.G. and M.H.; Writing-review \& editing, M.H., A.B., Y.S. and U.Y. All authors have read and agreed to the published version of the manuscript.

Funding: This project was financed by the center of fertilizer and plant nutrition (CFPN).

Acknowledgments: We would like to thank Luda, Ina Finegold, Yonatan Saroya, Jajaw Bimro, Behailu Kassahun and Fanosie Mekonen for assistance. Y.S. is the incumbent of the Haim Gvati Chair in Agriculture.

Conflicts of Interest: The authors declare no conflict of interest.

\section{References}

1. Roussis, I.; Folina, A.; Kakabouki, I.; Kouneli, V.; Karidogianni, S.; Chroni, M.; Bilalis, D. Effect of organic and inorganic fertilization on yield and yield components of teff [Eragrostis tef (Zucc.) Trotter] cultivated under Mediterranean semi-arid conditions. Sci. Pap. Ser. A Agron. 2019, 62, 138-144.

2. El-Alfy, T.S.; Ezzat, S.M.; Sleem, A.A. Chemical and biological study of the seeds of Eragrostis tef (Zucc.) Trotter. Nat. Prod. Res. 2012, 26, 619-629. [CrossRef] [PubMed]

3. Zhu, F. Chemical composition and food uses of teff (Eragrostis tef). Food Chem. 2018, 239, 402-415. [CrossRef] [PubMed]

4. Tatham, A.S.; Fido, R.J.; Moore, C.M.; Kasarda, D.D.; Kuzmicky, D.D.; Keen, J.N.; Shewry, P.R. Characterisation of the major prolamins of tef (Eragrostis tef) and finger millet (Eleusine coracana). J. Cereal Sci. 1996, 24, 65-71. [CrossRef]

5. Spaenij-Dekking, L.; Kooy-Winkelaar, Y.; Koning, F. The Ethiopian cereal tef in celiac disease. N. Engl. J. Med. 2005, 353, 1748-1749. [CrossRef] [PubMed]

6. Mengesha, M.H. Chemical composition of teff (Eragrostis tef) compared with that of wheat, barley and grain sorghum. Econ. Bot. 1966, 20, 268-273. [CrossRef]

7. Gebremariam, M.M.; Zarnkow, M.; Becker, T. Teff (Eragrostis tef) as a raw material for malting, brewing and manufacturing of gluten-free foods and beverages: A review. Food Sci. Technol. 2012, 51, 2881-2895. [CrossRef]

8. Tietel, Z.; Simhon, E.; Gashu, K.; Ananth, D.A.; Schwartz, B.; Saranga, Y.; Yermiyahu, U. Nitrogen availability and genotype affect major nutritional quality parameters of tef grain grown under irrigation. Sci. Rep. 2020, 10, 1-15. [CrossRef]

9. Ketema, S. Eragrostis tef (Zucc.) Trotter. Promoting the Conservation and Use of Underutilized and Neglected Crops; Bioversity International Publication: Rome, Italy, 1997; Volume 12, pp. 1-52.

10. Gelaw, A.M.; Qureshi, A.S. Tef (Eragrostis tef): A Superfood Grain from Ethiopia with Great Potential as an Alternative Crop for Marginal Environments. In Emerging Research in Alternative Crops; Springer: Cham, Switzerland, 2020; pp. 265-278.

11. Efrem, B. Performance of some cereal crops under drained Vertisols in the Ethiopian highlands. In Advances in Vertisols management in Ethiopian Highlands; Paulos, D., Asgelil, D., Asfaw, Z., Gezahegn, A., Abebe, K., Eds.; Ethiopian Institute of Agricultural Research: Addis Ababa, Ethiopia, 2001; pp. 151-157.

12. Chanyalew, S.; Ferede, S.; Damte, T.; Fikre, T.; Genet, Y.; Kebede, W.; Tolossa, K.; Zehirun, T.; Assefa, K. Significance and prospects of an orphan crop tef. Planta 2019, 250, 753-767. [CrossRef]

13. Lee, H. Teff, a rising global crop: Current status of teff production and value chain. Open Agric. J. 2018, 12, 185-193. [CrossRef]

14. Teklu, Y.; Tefera, H. Genetic improvement in grain yield potential and associated agronomic traits of tef (Eragrostis tef). Euphytica 2005, 141, 247-254. [CrossRef] 
15. Hawkesford, M.; Horst, W.; Kichey, T.; Lambers, H.; Schjoerring, J.; Møller, I.S.; White, P. Functions of macronutrients. In Marschner's Mineral Nutrition of Higher Plants; Academic Press: Cambridge, CA, USA, 2012; pp. 135-189.

16. IFDC. Assessment of Fertilizer Consumption and Use by Crop in Ethiopia. 2015. Available online: https://africafertilizer.org/wp-content/uploads/2017/05/FUBC-Ethiopia-Final-Report-2016.pdf (accessed on 23 September 2020).

17. Gebretsadik, H.; Haile, M.; Yamoah, C.F. Tillage frequency, soil compaction and N-fertilizer rate effects on yield of teff (Eragrostis tef (Zucc) Trotter) in central zone of Tigray, Northern Ethiopia. Momona Ethiop. J. Sci. 2009, 1. [CrossRef]

18. Assefa, K.; Erenso, T.F.; Banja, T.H. Phosphorus critical level and optimum nitrogen rate determination on teff for sustainable soil fertility management and economical teff production at Lume Area of Oromia region, Ethiopia. J. Agric. Biol. Healthc. 2017, 7, 2224-3208.

19. Wato, T. Effects of Nitrogen Fertilizer Rate and Inter-row Spacing on Yield and Yield Components of Teff [Eragrostis teff (Zucc.) Trotter] in Limo District, Southern Ethiopia. Int. J. Plant Soil Sci. 2019, 31, 1-12. [CrossRef]

20. Girma, K.; Reinert, M.; Ali, M.S.; Sutradhar, A.; Mosali, J. Nitrogen and phosphorus requirements of teff grown under dryland production system. Crop. Manag. 2012, 11, 1-14. [CrossRef]

21. O’Donovan, J.T.; Turkington, T.K.; Edney, M.J.; Clayton, G.W.; McKenzie, R.H.; Juskiw, P.E.; Lafond, G.P.; Grant, C.A.; Brandt, S.; Harker, K.N.; et al. Seeding rate, nitrogen rate, and cultivar effects on malting barley production. Agron. J. 2011, 103, 709-716.

22. Zhang, M.; Wang, H.; Yi, Y.; Ding, J.; Zhu, M.; Li, C.; Guo, W.; Feng, C.; Zhu, X. Effect of nitrogen levels and nitrogen ratios on lodging resistance and yield potential of winter wheat (Triticum aestivum L.). PLoS ONE 2017, 12, e0187543. [CrossRef]

23. Pan, J.; Zhao, J.; Liu, Y.; Huang, N.; Tian, K.; Shah, F.; Liang, K.; Zhang, X.; Liu, B. Optimized nitrogen management enhances lodging resistance of rice and its morpho-anatomical, mechanical, and molecular mechanisms. Sci. Rep. 2019, 9, 1-13. [CrossRef]

24. Kanter, D.R. Nitrogen pollution: A key building block for addressing climate change. Clim. Chang. 2018, 147, 11-21. [CrossRef]

25. Kidanu, S.; Tanner, D.G.; Mamo, T. Effect of nitrogen fertiliser applied to tef on the yield and $\mathrm{N}$ response of succeeding tef and durum wheat on a highland vertisol. Afr. Crop. Sci. J. 1999, 7. [CrossRef]

26. Habtegebrial, K.; Singh, B.R. Effects of timing of nitrogen and sulphur fertilizers on yield, nitrogen, and sulphur contents of Tef (Eragrostis tef (Zucc.) Trotter). Nutr. Cycl. Agroecosyst. 2006, 75, 213-222. [CrossRef]

27. Dereje, G.; Alemu, D.; Adisu, T.; Anbessa, B. Response of yield and yield components of Tef [Eragrostis tef (Zucc.) Trotter] to optimum rates of nitrogen and phosphorus fertilizer rate application in Assosa Zone, Benishangul Gumuz Region. Ethiop. J. Agric. Sci. 2018, 28, 81-94.

28. Szmidt, R.A.K.; Hall, D.A.; Hitchon, G.M. Development of perlite culture systems for the production of greenhouse tomatoes. In Symposium on Horticultural Substrates and Their Analysis; Acta Horticulturae: Brussels, Belgium, 1987; Volume 221, pp. 371-378.

29. Zhang, Y.; Wang, J.; Gong, S.; Xu, D.; Sui, J. Nitrogen fertigation effect on photosynthesis, grain yield and water use efficiency of winter wheat. Agric. Water Manag. 2017, 179, 277-287. [CrossRef]

30. Papadopoulos, I. Nitrogen fertigation of trickle-irrigated potato. Nutr. Cycl. Agroecosyst. 1988, 16, $157-167$. [CrossRef]

31. Vanitha, K.; Mohandass, S. Ass Drip fertigation could improve source-sink relationship of aerobic rice (Oryza sativa L.). Afr. J. Agric. Res. 2014, 9, 294-301.

32. Demirbas, A.; Akpinar, C.; Coskan, A.; Karakoy, T. Effects of different fertigation levels on maize yield and nutrient uptake under semi-arid Mediterranean conditions. Infrastruktura i Ekologia Terenów Wiejskich 2017, 727-736. [CrossRef]

33. Halpern, M.; Bar-Tal, A.; Lugassi, N.; Egbaria, A.; Granot, D.; Yermiyahu, U. The role of nitrogen in photosynthetic acclimation to elevated $\left[\mathrm{CO}_{2}\right.$ ] in tomatoes. Plant Soil 2018, 434, 397-411. [CrossRef]

34. García Lozano, M.; Escobar, I.; Berenguer, J.J. Green-pepper fertigation in soilless culture. In International Symposium on Soilless Culture and Hydroponics; Acta Horticulturae: Brussels, Belgium, 2004; Volume 697, pp. 543-547. 
35. Silber, A.; Bruner, M.; Kenig, E.; Reshef, G.; Zohar, H.; Posalski, I.; Yehezkel, H.; Shmuel, D.; Cohen, S.; Dinar, M.; et al. High fertigation frequency and phosphorus level: Effects on summer-grown bell pepper growth and blossom-end rot incidence. Plant Soil 2005, 270, 135-146. [CrossRef]

36. Omondi, J.O.; Lazarovitch, N.; Rachmilevitch, S.; Boahen, S.; Ntawuruhunga, P.; Sokolowski, E.; Yermiyahu, U. Nutrient use efficiency and harvest index of cassava decline as fertigation solution concentration increases. J. Plant Nutr. Soil Sci. 2018, 181, 644-654. [CrossRef]

37. Ben-Zeev, S.; Bimro, J.; Barak, V.; Saranga, Y. Phenotypic diversity and heritability in Eragrostis tef under irrigated Mediterranean conditions. Isr. J. Plant Sci. 2018, 65, 222-231. [CrossRef]

38. Yihun, Y.M.; Haile, A.M.; Schultz, B.; Erkossa, T. Crop Water Productivity of Irrigated Teff in a Water Stressed Region. Water Resour. Manag. 2013, 27, 3115-3125. [CrossRef]

39. Assefa, K.; Cannarozzi, G.; Girma, D.; Kamies, R.; Chanyalew, S.; Plaza-Wüthrich, S.; Biosch, R.; Rindisbacher, A.; Rafudeen, S.; Tadele, Z. Genetic diversity in tef [Eragrostis tef (Zucc.) Trotter]. Front. Plant Sci. 2015, 6, 177. [CrossRef] [PubMed]

40. Bedane, G.M.; Saukuru, A.M.; George, D.L.; Gupta, M.L. Evaluation of teff (Eragrostis tef [Zucc.] Trotter) lines for agronomic traits in Australia. Aust. J. Crop Sci. 2015, 9, 242.

41. Mariotti, F.; Tomé, D.; Mirand, P.P. Converting nitrogen into protein-Beyond 6.25 and Jones' factors. Crit. Rev. Food Sci. Nutr. 2008, 48, 177-184. [CrossRef] [PubMed]

42. Giday, O.; Gibrekidan, H.; Berhe, T. Response of Teff (Eragrostis tef) to Different Rates of Slow Release and Conventional Urea Fertilizers in Vertisols of Southern Tigray, Ethiopia. Adv. Plants Agric. Res. 2014, 1. [CrossRef]

43. Dagnaw, H.B. Influence of Nitrogen Fertilizer Rates and Varieties on Grain yield, Grain Nutrition and Injera Sensory Quality of Tef [Eragrostis tef (Zucc.) Trotter] Varieties. Master's Thesis, Adis Ababa University, Addis Ababa, Ethiopia, 2018.

44. Paff, K.; Asseng, S. A review of tef physiology for developing a tef crop model. Eur. J. Agron. 2018, 94, 54-66. [CrossRef]

45. Halse, N.J.; Greenwood, E.A.N.; Lapins, P.; Boundy, C.A.P. An analysis of the effects of nitrogen deficiency on the growth and yield of a Western Australian wheat crop. Aust. J. Agric. Res. 1969, 20, 987-998. [CrossRef]

46. Van Oosterom, E.J.; Borrell, A.K.; Chapman, S.C.; Broad, I.J.; Hammer, G.L. Functional dynamics of the nitrogen balance of sorghum: I. N demand of vegetative plant parts. Field Crop. Res. 2010, 115, 19-28. [CrossRef]

47. Massignam, A.M.; Chapman, S.C.; Hammer, G.L.; Fukai, S. Physiological determinants of maize and sunflower grain yield as affected by nitrogen supply. Field Crop. Res. 2009, 113, 256-267. [CrossRef]

48. Gungula, D.T.; Kling, J.G.; Togun, A.O. CERES-Maize predictions of maize phenology under nitrogen-stressed conditions in Nigeria. Agron. J. 2003, 95, 892-899. [CrossRef]

49. Birch, C.J.; Long, K.E. Effect of nitrogen on the growth, yield and grain protein content of barley (Hordeum vulgare). Aust. J. Exp. Agric. 1990, 30, 237-242. [CrossRef]

50. Williams, R.L.; Angus, J.F. Deep floodwater protects high-nitrogen rice crops from low-temperature damage. Aust. J. Exp. Agric. 1994, 34, 927-932. [CrossRef]

51. Hall, A.J.; Savin, R.; Slafer, G.A. Is time to flowering in wheat and barley influenced by nitrogen? A critical appraisal of recent published reports. Eur. J. Agron. 2014, 54, 40-46. [CrossRef]

52. Gashu, K. Response of teff (Eragrostis Tef (Zucc.) Trotter) to Nitrogen, Phosphorus, and Potassium Fertilization. Master's Thesis, H. Smith Fuculty of Agriculture, Food, and Environment of the Hebrew University of Jerusalem, Jerusalem, Israel, 2017.

53. Mulugeta, D.; Mamo, T.; Sokolowski, E.; Nachmansohn, J. Potash fertilization of teff and wheat in the highlands of Ethiopia. Electron. Int. Fertil. Corresp. 2017, 48, 12-19.

54. Demiss, M.; Beyene, S.; Kidanu, S. Biomass accumulation and potassium concentrations in tissue of Teff (Eragrostis tef Zucc. Trotter) at three growth stages in Vertisols and Nitisols of the Central Highlands of Ethiopia. Afr. J. Agric. Res. 2019, 146, 345-353.

55. EthioSIS (Ethiopia Soil Information System). Soil Fertility Status and Fertilizer Recommendation Atlas for Tigray Regional State; Agricultural Transformation Agency: Ethiopia, Addis Ababa, 2014.

56. Misskire, Y.; Mamo, T.; Taddesse, A.M.; Yermiyahu, U. The effect of potassium on yield, nutrient uptake and efficiency of teff (Eragrostis tef Zucc. Trotter) on vertisols of North Western Ethiopian Highlands. J. Plant Nutr. 2019, 42, 307-322. [CrossRef]

57. Albornoz, F. Crop responses to nitrogen overfertilization: A review. Sci. Hortic. 2016, 205, 79-83. [CrossRef] 
58. Tesfahunegn, G.B. Response of Yield and Yield Components of Tef [Eragrostis tef (Zucc.) Trotter] to Tillage, Nutrient, and Weed Management Practices in Dura Area, Northern Ethiopia. Int. Sch. Res. Not. 2014, 2014, 1-9. [CrossRef]

59. Tesfay, T.; Gebresamuel, G. Agronomic and economic evaluations of compound fertilizer applications under different planting methods and seed rates of tef [Eragrostis tef (Zucc.) Trotter] in Northern Ethiopia. J. Drylands 2016, 6, 409-422.

60. Gebrehawariyat, F.M.; Haile, W.; Mamo, T.; Zipori, I.; Sokolowski, E. Response of teff [Eragrostis tef (Zucc.) Trotter] to potassium fertilizer application in four districts of North Shewa, Ethiopia. Electron. Int. Fertil. Corresp. 2018, 53, 3-15.

61. Ben-Zeev, S.; Rabinovitz, O.; Orlov-Levin, V.; Chen, A.; Graff, N.; Goldwasser, Y.; Saranga, Y. Less Is More: Lower Sowing Rate of Irrigated Tef (Eragrostis tef) Alters Plant Morphology and Reduces Lodging. Agronomy 2020, 10, 570. [CrossRef]

62. Van Delden, S.H. On Seed Physiology, Biomechanics and Plant Phenology in Eragrostis tef. Ph.D., Dissertation, Wageningen University, Wageningen, The Netherlands, 2011. Available online: https://library.wur.nl/ WebQuery/wurpubs/fulltext/169451 (accessed on 5 November 2020).

63. Lemaire, G.; Jeuffroy, M.H.; Gastal, F. Diagnosis tool for plant and crop N status in vegetative stage: Theory and practices for crop N management. Eur. J. Agron. 2008, 28, 614-624. [CrossRef]

64. Justes, E.; Mary, B.; Meynard, J.M.; Machet, J.M.; Thelier-Huché, L. Determination of a Critical Nitrogen Dilution Curve for Winter Wheat Crops. Ann. Bot. 1994, 74, 397-407. [CrossRef]

65. Colnenne, C.; Meynard, J.M.; Reau, R.; Justes, E.; Merrien, A. Determination of a Critical Nitrogen Dilution Curve for Winter Oilseed Rape. Ann. Bot. 1998, 81, 311-317. [CrossRef]

66. Ata-Ul-Karim, S.T.; Liu, X.; Lu, Z.; Zheng, H.; Cao, W.; Zhu, Y. Estimation of nitrogen fertilizer requirement for rice crop using critical nitrogen dilution curve. Field Crop. Res. 2017, 201, 32-40. [CrossRef]

67. Monostori, I.; Árendás, T.; Hoffman, B.; Galiba, G.; Gierczik, K.; Szira, F.; Vágújfalvi, A. Relationship between SPAD value and grain yield can be affected by cultivar, environment and soil nitrogen content in wheat. Euphytica 2016, 211, 103-112. [CrossRef]

Publisher's Note: MDPI stays neutral with regard to jurisdictional claims in published maps and institutional affiliations.

(C) 2020 by the authors. Licensee MDPI, Basel, Switzerland. This article is an open access article distributed under the terms and conditions of the Creative Commons Attribution (CC BY) license (http://creativecommons.org/licenses/by/4.0/). 